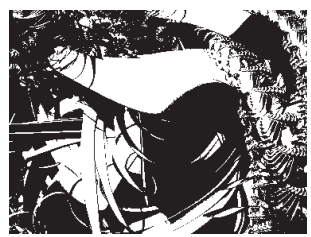

doi:10.5559/di.20.1.04

\title{
SOCIODEMOGRAFSKE ODREDNICE ZAPOSLENOSTI ŽENA U HRVATSKOJ
}

Jakov GELO, Šime SMOLIĆ, Marin STRMOTA

Ekonomski fakultet, Zagreb

UDK: $331.101 .232-055.2(497.5)$

$331.101 .25-055.2(497.5)$

$314.17(497.5): 331$

314.145(497.5):331

Izvorni znanstveni rad

Primlieno: 19. 7. 2010.

U radu utvrđujemo učinak odabranih sociodemografskih prediktora - dob, obrazovanje, broj djece, bračni status žena i imanje predškolskoga djeteta - na zaposlenost žena u Hrvatskoj. U prvom dijelu rada donosimo opsežan pregled literature, koja se temelji na istraživanjima o uzrocima i posljedicama participacije žena na tržištu rada. Empirijska analiza provedena je upotrebom podataka iz Ankete o radnoj snazi (ARS) za II. i IV. kvartal 2007. godine. Ukupan uzorak obuhvatio je 2462 žene od 20 do 39 godina, s time da su iz uzorka prema položaju u aktivnosti izbačene učenice i studentice te slabo zastuplieni oblici bračnoga statusa žena (udovice, rastavljene itd.). U drugom dijelu rada deskriptivnom analizom stavili smo u odnos odabrane prediktorske varijable i tri modaliteta kriterijske varijable. Multinomnom logističkom regresijom, ekstenzijom logističke regresije, procijenili smo dva modela - nezaposlenih, odnosno neaktivnih - žena u odnosu na zaposlene, ti. referentnu kategoriju i utvrdili značajne prediktore zaposlenosti žena. Obrazovanje, broj djece, dob žene, bračni status i imanje predškolskoga djeteta mogu se smatrati značajnim čimbenicima zaposlenosti žena u Hrvatskoj.

Ključne riječi: participacija žena na tržištu rada, obrazovanje žena, broj djece, zaposlenost 
Jedna od najvažnijih promjena u životima žena u drugoj polovici 20. stoljeća povezana je s porastom zaposlenosti žena na plaćenim poslovima izvan kućanstva. Put do danas relativno visokih stopa zaposlenosti žena nije bio jednostavan i pod stalnim je utjecajem brojnih sociodemografskih čimbenika, uz izražene europske regionalne razlike. Osim mogućnosti zarade, na odluke žena o sudjelovanju u plaćenom radu izvan kućanstva utječe više čimbenika, između kojih, kao važnije, možemo izdvojiti dob žene, bračni status, broj djece, dob djeteta (djece), razinu obrazovanja, ukupan dohodak obitelji, dohodak supruga i dr.

Prema mnogima, spol i dob najstarija su forma podjele rada, koja je i danas u 21. stoljeću temelj podjele poslova na tržištu rada, a tržište rada postoji kao poseban i veoma bitan dio života i žene i muškarca na koji otpada velik dio životne dobi. Mnogi aspekti osobnoga, obiteljskoga, ali i profesionalnoga života žene uvjetovani su u velikoj mjeri, a ponekad i isključivo, dobi. Nadalje, porast obrazovanosti žena utjecao je na smanjenje nezaposlenosti, ali njihov status na tržištu rada ne odražava potpuno obrazovna dostignuća. Žene se još suočavaju s mnogim zaprekama pri ulasku i napredovanju na tržištu rada, npr. na istim poslovima često zarađuju manje nego muškarci. Eliminacija diskriminacije i slabljenje segregacije poslova po spolu, koje Topolčić (2008.) ističe kao neizostavne čimbenike zapošljavanja žena, nisu izjednačili prosječne zarade žena i muškaraca. Stupanje u brak za ženu koja je zaposlena često znači preuzimanje uloge sekundarnoga stvaratelja dohotka (Hakim, 2003.a). Međunarodna iskustva pokazuju da žene nakon stupanja $u$ brak provode više vremena $u$ obavljanju kućanskih i drugih obiteljskih poslova nego njihovi muževi (Topolčić, 2001.). Izlasci žena iz zaposlenosti potaknuti imanjem (djeteta) djece umanjuju radno iskustvo (ljudski kapital), otežavaju povratak $u$ zaposlenost i zadržavanje rukovodećih pozicija na poslu - u slučaju većega broja djece atrofija ljudskoga kapitala bit će izraženija. Sve navedeno povećava ranjivost žena na tržištu rada i može dovesti do porasta nezaposlenosti - često su žene "prve na redu" kod otpuštanja zbog negativnih fluktuacija u gospodarstvu. Pod utjecajem podjele poslova prema spolu stope nezaposlenosti žena više su nego kod muškaraca, a mogli bismo reći da su financijski kažnjene zbog imanja djece. Uvriježeni stavovi da žene trebaju zadržati glavne uloge u podizanju djece i poslovima u kućanstvu potvrđeni su u mnogim istraživanjima. Hakim (2003.b) donosi prikaz istraživanja Eurobarometar iz 1987. godine o očekivanim ulogama među spolovima u Španjolskoj i Velikoj Britaniji - gotovo tri četvrtine žena i muškaraca poduprlo je za- 
DRUŠ. ISTRAŽ. ZAGREB GOD. 20 (2011), BR. 1 (111)

STR. 69-88

GELO, J., SMOLIĆ, Š. STRMOTA, $M$. SOCIODEMOGRAFSKE. pošljavanje žena, ali velika većina ispitanika također je sklona mišljenju da bi žene trebale zadržati sve glavne uloge u kućanstvu. Oko jedne četvrtine udanih ispitanica preferira segregaciju obiteljske uloge i uloge na tržištu rada, a njihov konačni izlazak s tržišta rada nastupa nakon udaje, ako su uopće ikada radile. Ovakve oblike sudjelovanja žena na tržištu rada nazvala je modernom podjelom rada u obitelji prema spolu.

Specifična dvojna uloga žena, kao majki i kućanica te kao ravnopravnih sudionica na tržištu rada, ograničuje njihovu zaposlenost na plaćenim poslovima izvan kućanstva. ${ }^{1}$ Treas i Widmer (2000.) grupirali su odabrane europske zemlje s obzirom na stavove o zaposlenosti udanih žena. $U$ njihovu istraživanju zemlje poput Bugarske, Češke, Mađarske, Poljske i Slovenije nalaze se u grupi "majčinstvu orijentiranih" društava. ${ }^{2}$ Ispitanici u tim zemljama preferiraju zaposlenost žena u punom radnom vremenu prije i nakon rođenja djeteta, smatraju da majke s predškolskim djetetom ne bi trebale raditi, a zaposlenost $\mathrm{s}$ nepunim radnim vremenom neznatno im je poželjnija od rada s punim radnim vremenom ili ostanka kod kuće.

Žene u zaposlenju pronalaze alternativu ulozi kućanice ili priliku za dogradnju uloge u obitelji. Zadržavanje dominantne uloge u odgoju djece, uz ostvarivanje dodatnoga prihoda, nije veći izazov ulozi muškarca hranitelja obitelji. Alternativa ulozi kućanice ogleda se u ravnopravnom sudjelovanju žena u stvaranju prihoda kućanstva, ali i ravnomjernoj podjeli poslova u kućanstvu (Hakim, 2003.b; Mendras, 2004.). Istražujući tipologiju rodnih režima Mósesdóttir, Topolčić (2008., 1039) zaključuje da "razvoj ravnopravnijih odnosa među bračnim partnerima uključuje uravnoteženiju alokaciju plaćenog i neplaćenog rada u obitelji, a ulazak u radnu snagu žena majki najočitiji je pokazatelj kraja dominacije modela muškarca hranitelja obitelji".

Povijesno gledajući, stope zaposlenosti žena na plaćenim poslovima izvan kućanstva nikada nisu bile na tako visokim razinama kao danas, iako uz još uvijek izražene razlike $u$ odnosu na muškarce. U posljednja tri desetljeća mogu se jasno izdvojiti dvije činjenice o stopama aktivnosti žena. Do porasta stopa aktivnosti (priljevi žena iz Marxove rezervne armije radne snage) zbog gospodarskoga rasta došlo je u gotovo svim zemljama, a s druge strane sve izraženija je heterogenost u razinama i uzorcima aktivnosti žena među zemljama.

\section{ODREDNICE ZAPOSLENOSTI ŽENA}

Teorijsku razradbu modela ponude rada žena nalazimo u mnogim radovima, primjerice Mincera (1985.), koji je promatrao ponudu rada tijekom radnoga vijeka žene. Prema mode- 
DRUŠ. ISTRAŽ. ZAGREB GOD. 20 (2011), BR. 1 (111)

STR. 69-88

GELO, J., SMOLIĆ, Š., STRMOTA, M.: SOCIODEMOGRAFSKE. nja tijekom života utječu na izbor trenutka participacije u radnoj snazi, a ne na ukupan opseg ponude rada. Neoklasična ekonomska teorija govori da su odluke žena o zaposlenju rezultat interakcije troškova i koristi između plaćenoga rada na tržištu u odnosu na ostale poslove, poput rada u kućanstvu i dokolice. Međutim, Berk i Berk (1983.) osvrću se na probleme teorije ljudskoga ponašanja "New Home Economics" (NHE). Smatraju da malen broj pretpostavki ocrtava čitavu teorijsku strukturu i da su iste previše pojednostavnjene. NHE počiva na proizvodnoj funkciji kućanstva, pri čemu obitelji nastoje maksimizirati blagostanje (maksimizirati korisnost) uz dane financijske resurse i raspoloživo vrijeme. Kućanstva alociraju vrijeme između rada na tržištu, proizvodnje kućanskih dobara i investiranja u ljudski kapital (problem alokacije rješavaju poput malih poduzeća). Samo obitelji koje se primaknu optimalnoj alokaciji svojih resursa mogu opstati; sociolozi u ovom slučaju trebaju istražiti postoji li oblik "prirodne selekcije" koji je naklonjen efikasnim kućanstvima i njegovo funkcioniranje. Pojedine pretpostavke NHE sociolozi koji proučavaju aktivnost obitelji na mikrorazini stavljaju pod upitnik. Izdvajamo pretpostavku stabilnih preferencija; isključenja zajedničke proizvodnje (vrlo raširena u kućanstvima); slabe separabilnosti funkcije korisnosti kućanstva (kod proizvodnje kućanstva može se jasno odvojiti relativni doprinos pojedinog inputa); konstantnih prinosa na opseg proizvodnje u kućanstvu (i uz jasno definirana kućanska dobra teško ostvarivo).

Heckman i Macurdy (1980.) istraživali su model životnoga ciklusa u ponudi rada žene i empirijskom analizom potvrdili da ukupan broj djece i djeca predškolske dobi povećavaju potražnju za vremenom provedenim kod kuće. Veći broj djece u obitelji smanjuje bogatstvo isto kao što rađanje ograničuje financijske resurse kućanstva, smanjujući aktivnost žena na tržištu rada. Mincer je (1985.) istraživao stope participacije na uzorku od 12 razvijenih zemalja i zaključio da trend rasta zaposlenosti postoji među udanim ženama. Uvidom $\mathrm{u}$ statistike pojedinih zemalja, a osobito onih razvijenih, primjetno je stalno smanjenje jaza zaposlenosti između žena i muškaraca. Ipak, u mnogim zemljama to nije tako, tj. stopa zaposlenosti žena još je uvijek niža od iste za muškarce (Eurostat, 2010.). Tradicionalno, mediteranske zemlje karakteriziraju niske stope zaposlenosti žena. Neki od razloga niske participacije žena u tim zemljama jesu nedostatna ponuda javne skrbi za djecu, slaba ponuda radnih mjesta s nepunim radnim vremenom $\mathrm{i}$ kratki rodiljni dopusti. U tom slučaju jedina alternativa poslovima s punim radnim vremenom jest nezaposlenost (Del Boca i sur., 2004.). Hakim je (2003.a) na temelju analize Nacionalne ankete o radnoj snazi SAD-a pokazala da su šanse 
DRUŠ. ISTRAŽ. ZAGREB GOD. 20 (2011), BR. 1 (111)

STR. 69-88

GELO, J., SMOLIĆ, Š., STRMOTA, $M$. SOCIODEMOGRAFSKE... zaposlenja žena koje su konstantno planirale raditi bile veće za $30 \%$, a uključenost žena u plaćenom radu izvan kućanstva rezultat je relativno fiksnih preferencija. Preferencije je klasificirala u tri skupine: u prvoj su žene isključivo orijentirane na kućanstvo (obitelj), druga skupina je adaptivna, a treća skupina žena isključivo je fokusirana na posao. Svaka od te tri skupine drukčije reagira na promjenu socijalne politike, ima drukčiji odnos prema radu, obitelji, rađanju djece itd.

Žena koja uobičajeno preuzima brigu o djeci, a želi sudjelovati na tržištu rada, mora ili ograničiti rađanje ili pronaći alternativne načine skrbi o djeci. Brojne empirijske studije upućuju na postojanje povezanosti fertiliteta i participacije žena u radnoj snazi (Becker, 1981.; Mincer, 1985.; Rindfuss i Brewster, 1996.; Brewster i Rindfuss, 2000.; Billari i Kohler, 2002.; Engelhardt i sur., 2004.). Do sredine 1980-ih godina odnos između fertiliteta i participacije žena u zaposlenosti, promatran na makrorazini, bio je negativan, ali predznak nakon toga postaje pozitivan. Za razliku od razdoblja prije 1980 . godine, korelacija između fertiliteta i zaposlenosti žena postaje volatilnija (Del Boca i Pasqua, 2005.; Engelhardt i sur., 2004.). Danas zemlje s većom participacijom žena u radnoj snazi imaju u prosjeku veći broj djece. U razvijenim europskim zemljama 1980-ih je zabilježen trend povratka majki na posao unutar godine dana od porođaja i između dva porođaja. Takav bimodalni uzorak zaposlenosti poprimio je oblik nečega što izgleda kao kontinuirana zaposlenost $\mathbf{u}$ većini europskih zemalja (Hakim, 2004.). Govoreći o odnosu fertiliteta i zaposlenosti, nameće se problem kompatibilnosti uloga, odnosno uloge žene radnice i uloge žene majke. "Povećanje kompatibilnosti tih dviju uloga dovodi do smanjenja njihove međusobne ovisnosti, pa jedno nije ograničenje za drugo" (Rindfuss i Brewster, 1996., 263). Kako navodi Leinert Novosel (2003.), središnji problem europske politike prema ženama upravo je usklađivanje zaposlenosti i obiteljskoga života kao preduvjeta svih promjena vezanih uz društveni položaj žena. Žene u ekonomski razvijenim društvima čuvanje i odgoj djece mogu prepustiti veoma dobro organiziranom sustavu ustanova za brigu o predškolskoj djeci. Mjera u kojoj se žene mogu osloniti na alternativne načine brige o djeci smanjuje percipiranu nekompatibilnost između rada i majčinstva. Rindfuss i Brewster (1996.) naglašavaju ulogu rodbine u smanjenju spomenute nekompatibilnosti. Proučavajući specifične stope participacije žena u razvijenim zemljama, Brewster i Rindfuss (2000.) uočavaju da se sve više udanih žena koje imaju djecu vraća u radnu snagu $\mathrm{u}$ srednjim tridesetima, $\mathrm{u}$ pravilu kada najmlađe dijete dostigne školsku dob. Takvu promjenu u ponašanju žena, s obzirom na participaciju u radnoj snazi, proizveo je tzv. profil zaposlenosti u obliku slova " $M$ ". Isprekidana participacija jedan je 
DRUŠ. ISTRAŽ. ZAGREB GOD. 20 (2011), BR. 1 (111)

STR. 69-88

GELO, J., SMOLIĆ, Š., STRMOTA, M.: SOCIODEMOGRAFSKE. od mogućih odgovora na međusobnu konkurenciju (konflikt) potražnje za radom i rađanjem. Po Beckerovu mišljenju (1965.), briga o djeci primjer je aktivnosti koja se manifestira kroz relativno velike propuštene zarade, a ne može se smatrati dokolicom, vremenski je intenzivna i ne smatra se produktivnom. ${ }^{3}$ Pojedine zemlje, kao npr. Švedska, politikama kompenzacije dohotka i obiteljskih dopusta povećale su ukupnu participaciju žena u radnoj snazi, pogotovo kod žena s dvoje i više djece. U Americi je uočen trend trostrukoga povećanja participacije majki predškolske djece od 1960. do 1991. godine, a prosječno izbivanje s posla nakon porođaja svelo se na samo tri mjeseca (Rindfuss i Brewster, 1996.). Stier i sur. (2001.) navode kako je zaposlenost žena s nepunim radnim vremenom alternativa prekidu zaposlenosti, a djeluje kao spona do pune zaposlenosti u kasnijem životu žene. Prekid zaposlenosti kod žena nije nimalo poželjan i kažnjava se smanjenom mogućnošću povratka na posao i manjom budućom zaradom.

Imanje djeteta i djetetova dob svakako se mogu povezati sa zaposlenosti žena. U razdoblju rađanja i podizanja djece participacija žene u radnoj snazi negativno je korelirana s brojem djece. "Prisutnost mlađega djeteta u obitelji povećava vrijednost vremena posvećenoga kućanstvu (radi se o proizvodnji dobra visoke vrijednosti), pa raste alokacija vremena posvećenoga kućanstvu" (Berk i Berk, 1983., 379). Dob i prisutnost drugoga djeteta također određuju vrijeme napuštanja i povratka majke na posao. Stier i sur. (2001.) dramatične promjene u zaposlenosti žena povezuju s imanjem djeteta predškolske dobi. Wenk i Garrett (1992.) dokazali su da prisutnost djece predškolske dobi ne utječe bitno na brzinu povratka majki na posao, ali je veza između dodatnoga porođaja i brzine povratka izrazito negativna. Bianchi (2000.) navodi kako majke u Americi danas ne provode ništa manje vremena $\mathrm{s}$ djecom, a razlog tome je precjenjivanje vremena koje su provodile s djecom u prošlosti, vremena koje im oduzima posao i sl. Prisutnost i dob djeteta utječu na participaciju žena u plaćenom radu izvan kućanstva, ali i na obilježja same participacije. Pod oblikom participacije misli se na poslove s punim i nepunim radnim vremenom, koji su posebno razvijeni $u$ skandinavskim zemljama. Hakim (2003.b) tvrdi kako se stope zaposlenosti u punom radnom vremenu u zemljama južne Europe ne razlikuju od onih u zemljama sjeverne Europe. Zemlje južne Europe još nemaju značajnije udjele zaposlenih žena na stalnim poslovima u nepunom radnom vremenu. Ipak, nepuna zaposlenost nije rješenje problema, jer bi prihvaćanje takvih poslova dugoročno pogoršalo položaj žene na tržištu rada (Stier i sur., 2001.). Dok žene pridonose rastu obitelj- 
DRUŠ. ISTRAŽ. ZAGREB GOD. 20 (2011), BR. 1 (111)

STR. 69-88

GELO, J., SMOLIĆ, Š. STRMOTA, $M$. SOCIODEMOGRAFSKE. skoga dohotka, a samim tim im se otvara mogućnost povećanja broja djece, $\mathrm{u}$ isto vrijeme moraju ograničiti rađanje zbog propuštenih zarada. Veći broj djece zahtijeva mnogo više vremena, a prekidi u karijeri zbog rađanja djece negativno se odražavaju na buduća dostignuća na poslu. "Ekstenzivna specijalizacija i podjela rada u kućanstvima, posebno između žena koje se brinu o djeci i muškaraca koji participiraju na tržištu rada, potiče smanjenje odgovornosti i ostalih napora u poboljšanju vlastita blagostanja na štetu drugih članova obitelji" (Becker, 1981., 10). ${ }^{4}$ Waldfogel je (1997.) istraživala kako imanje djece utječe na nadnice žena i zaključila da su zaposlene žene s djecom, u odnosu na žene bez djece, kažnjene nižim nadnicama. Treba naglasiti da je izbor karijere kućanice, žene koja se posvećuje podizanju djece i domu, vrlo riskantan potez. U suvremenim okolnostima, osoba koja se posveti kućanstvu izlaže se riziku da godinama akumulira "krivu" vrstu ljudskoga kapitala - onoga koji se teško može tržišno vrednovati. Istodobno ona ne skuplja nova iskustva (i staž) na tržištu rada, a znanja i vještine vezani uz njezino zanimanje ili profesiju zastarijevaju (Topolčić, 2008.).

Razina obrazovanja značajno utječe na participaciju, odnosno odluku o definitivnom ili prijevremenom izlasku žena iz radne snage. U razvijenim društvima obrazovanje žene važno je za postizanje kompatibilnosti uloge majke i radnice, jer su za neka zanimanja radno vrijeme i uvjeti rada danas mnogo fleksibilniji i olakšavaju njihovo ispunjenje (Brewster i Rindfuss, 2000.). Becker (1962.) postavlja hipotezu prema kojoj su žene manje motivirane za stjecanje novih radnih vještina, jer provode manje vremena u zaposlenosti od muškaraca. U velikom broju razvijenih zemalja obrazovanije žene na poslovima koji zahtijevaju dugotrajno usavršavanje u manjoj mjeri napuštaju posao, ali se nakon odlaska i brže vraćaju (Jaumotte, 2003.). Ta teza potvrđena je u mnogim presječnim istraživanjima i odražava jaku vezu između obrazovanja i orijentacije žene prema izgradnji karijere. Žene se ne usmjeravaju automatski na izgradnju karijere samo zato što imaju visok stupanj obrazovanja, iako im posjedovanje takvih kvalifikacija omogućuje lakši pristup i veće zarade na tržištu rada (Hakim, 2003.b). U pravilu, manje obrazovane žene imaju manju vjerojatnost ostanka i kontinuiteta u punoj zaposlenosti od žena s višim stupnjem obrazovanja. ${ }^{5}$ Stupanj obrazovanja i broj djece moguće je povezati s kontinuitetom žena u zaposlenosti. "Za žene čije su nadnice relativno niže u usporedbi s visokim troškovima brige o djeci racionalnija je odluka izlazak s tržišta rada i privremeno preuzimanje brige o njima" (Wenk i Garrett, 1992., 50). Snažniji utjecaj broja djece na zaposlenost očekuje se kod žena s nižim stupnjem obrazovanja 
DRUŠ. ISTRAŽ. ZAGREB GOD. 20 (2011), BR. 1 (1 1111$)$

STR. 69-88

GELO, J., SMOLIĆ, Š., STRMOTA, M.: SOCIODEMOGRAFSKE.
(Hakim, 2004.). Becker i Lewis (1973.) smatraju da viši stupanj obrazovanja majki značajno i pozitivno utječe na kvalitetu, a negativno na broj djece. Mincer (1985.) kao supstitucijske varijable u modelu dohotka uzima nadnice i obrazovanje žena, a pokazalo se da su one snažno i pozitivno povezane sa stopom participacije. Propuštene zarade tijekom neaktivnosti veće su kod obrazovanijih žena, što dodatno utječe na odluke o zaposlenju. Očekuje se da viši stupanj obrazovanja, koji se ogleda $u$ višim rezervacijskim nadnicama, snažno i pozitivno utječe na sudjelovanje žena u radnoj snazi (Ekert-Jaffe i Stier, 2009.). Na temelju empirijskog istraživanja "National Longitudinal Survey of Youth", Wenk i Garrett (1992.) dolaze do zaključka da starije majke s visokim stupnjem obrazovanja i atraktivnijim poslovima imaju manju vjerojatnost napuštanja posla oko termina porođaja od onih mlađih i manje obrazovanih. Heckman i Macurdy (1980.) naglašavaju da je povezanost obrazovanja i participacije rezultanta dvaju odvojenih efekata: pozitivnog efekta na bogatstvo i pozitivnog efekta na potražnju za dokolicom.

Jedan od važnijih faktora koji utječe na odluku žena o sudjelovanju na tržištu rada jest bračni status. Brak je institucija koja organizira "proizvodnju" u kućanstvu, a rad u kućanskoj proizvodnji alternativa je plaćenom radu na tržištu rada (Grossbard-Shechtman, 2003.). Još je prije gotovo pola stoljeća nobelovac Gary Becker proširio jednostavan model individualne ponude rada, $u$ kojem pojedinac bira između rada na tržištu rada i dokolice. U svom modelu uvodi jedinicu kućanstva, koja sad donosi odluke umjesto pojedinca. Prema tom modelu, u bračnoj će zajednici npr. žena donositi odluku o svom zaposlenju ovisno o položaju supruga u zaposlenju, ali i obratno. Ako uzmemo ženu kao onu koja će percipirati financijsko stanje u obitelji i na temelju toga donositi odluku o participaciji, onda je logika ovakva: u slučaju povećanja muževa prihoda, ženi postaje dostupan sve veći transferni dohodak u kućanstvu, pa se posljedični efekt dohotka odbija od participacije na tržištu rada. Ova logika sugerira veću vjerojatnost participacije na tržištu rada žena iz obitelji s niskim primanjima, zbog ekonomske nužnosti, dok će si obitelj s većim suprugovim prihodima moći priuštiti luksuz da žena proizvodi "dobra" u kućanstvu (McConnell i sur., 2007.). Wenk i Garrett (1992.) objašnjavaju da se u ranijim istraživanjima prisutnost bračnoga partnera negativno odražavala na zaposlenost žena, ali su oni dokazali suprotno. Majke s bračnim partnerom ili drugom odraslom osobom u kućanstvu vraćaju se na tržište rada mnogo brže nakon porođaja. Iako se danas bitno mijenja sama funkcija braka i obitelji, takvi modeli upućuju na važnost daljnjega proučavanja kohabitacije bilo u obliku 
DRUŠ. ISTRAŽ. ZAGREB GOD. 20 (2011), BR. 1 (111)

STR. 69-88

GELO, J., SMOLIĆ, Š. STRMOTA, $M$. SOCIODEMOGRAFSKE. braka ili nekoga drugog oblika suživota, jer obrasci ponašanja unutar takvih zajednica često stvaraju norme koje se prenose i na tržište rada.

Dob je uz spol izvorno biološka odrednica i kao takva utječe na strukturu i opseg ponude radne snage. U tradicionalnim, ali i modernim, društvima ponuda radne snage ovisit će o spolnoj strukturi, uz pretpostavku ceteris paribus, i to tako da će u zemlji u kojoj je udio žena veći od udjela muškaraca u radnoj dobi ekonomska aktivnost stanovništva biti niža. U slučaju niže ekonomske aktivnosti, uzrokovane većim udjelom žena u radnoj dobi, veća će biti i opterećenost ekonomski aktivnoga dijela stanovništva uzdržavanima (neaktivnima). Participacija u svijetu rada odvija se u okviru životnoga ciklusa i najčešće počinje izlaskom iz obrazovanja, a završava odlaskom u neki oblik mirovine. Sigurna je činjenica da participacija $u$ radnoj snazi nije ravnomjerna u svim dobnim skupinama stanovništva. Vidljivo je to iz podataka o stopama aktivnosti žena u Hrvatskoj u radu T. Matkovića (2008.). Aktivnost žena najveća je između 25 i 54 godine (tzv. "prime-age") i u većini razvijenih zemalja premašuje $70-80 \% .6$ Niže stope aktivnosti obilježavaju žene između 15 i 24 zbog školovanja, a nakon 54 . godine zbog prijevremenog ili zakonski uvjetovanog umirovljenja (Jaumotte, 2003.).

U nastavku rada usredotočujemo se na recentna istraživanja položaja žena na tržištu rada u Hrvatskoj. Zbog socijalne i obiteljske politike u bivšim socijalističkim zemljama žene su bile uvučene $u$ svijet rada, pa je prijelaz žene iz kućanstva u status zaposlenosti bio mnogo brži nego u demokratskim zemljama (Leutar, 2004.). Visoke stope nezaposlenosti i nizak životni standard u tim zemljama dovoljan su poticaj zapošljavanju žena (Topolčić, 2008.). Unatoč zakonskoj regulativi, rodna nejednakost $\mathrm{u}$ hrvatskom društvu i dalje tvrdokorno ustrajava, kršeći pritom razne zakonske odredbe, osobito u slučaju žena i prilikom njihova zapošljavanja. Iz istraživanja rodne nejednakosti i šansi prilikom zapošljavanja na uzorku nezaposlenih žena (Galić i Nikodem, 2009.) izdvajamo nekoliko važnih zaključaka: (1) u hrvatskoj javnosti postoji snažna percepcija nejednakosti društvenoga statusa muškaraca i žena; (2) prema obrazovnoj strukturi, najviše je dugotrajno nezaposlenih žena (duže od 8 godina) s nezavršenom osnovnom školom; (3) visokoobrazovane ili barem srednjeobrazovane žene brže pronalaze posao. Ukupna je zaposlenost žena od početka pedesetih pa do kraja osamdesetih godina povećana za gotovo sedam puta, a stalan rast udjela žena u ukupnoj zaposlenosti nastavio se do 1997. godine (Kerovec, 2003.). Aktivnost muškaraca $\mathrm{i}$ žena $\mathrm{u}$ radnom kontingentu na temelju mikropodataka hrvatske ankete o radnoj snazi detalj- 
DRUŠ. ISTRAŽ. ZAGREB GOD. 20 (2011) BR. 1 (111)

STR. 69-88

GELO, J., SMOLIĆ, Š., STRMOTA, M.: SOCIODEMOGRAFSKE. no je istražio T. Matković (2008.). Između 1996. i 2006. godine stopa zaposlenosti žena iznosila je između $54,6 \%$ i $57,9 \%$. Rodni jaz u stopi aktivnosti muškaraca i žena varirao je između 11,5 i 14,3 postotnih bodova. Stopa nezaposlenosti žena sredinom 1990-ih bila je 10-15\% veća od stope nezaposlenosti muškaraca, a nakon rasta 2000. godine, zbog gospodarskoga rasta, razlika se znatno povećala. Prema podacima za 2009. godinu (Eurostat, 2010.), stopa zaposlenosti žena u Hrvatskoj u radnoj dobi (15-59) iznosila je 55,1\%. Najviše specifične stope zaposlenosti imale su žene u dobnim skupinama od 30 do $34 \mathrm{i}$ od 35 do 39 godina (obje 74,3\%). Anketa o radnoj snazi daje uvid u trendove zaposlenosti i nezaposlenosti, pa je tako stopa aktivnosti osoba u zreloj dobi (25-54) od 1996. do 2006. ostala ista i varira oko $80 \%$, a stopa aktivnosti mladih (15-24) smanjuje se. Participacija u svijetu rada snažno je povezana s razinom obrazovanja. ${ }^{7}$ Obrazovanije osobe lakše pronalaze posao, dulje ostaju zaposlene, imaju veće plaće i veću zaštitu od nezaposlenosti. Muškarci u Hrvatskoj bez obrazovanja ili $\mathrm{s}$ nesveučilišnim studijem rade nešto prestižnije poslove nego žene istog obrazovanja (Matković, 2008.). Niža zaposlenost žena može se dovesti u vezu i s nedostatkom formalnih oblika skrbi za djecu, fleksibilnoga radnog vremena itd. S ovim problemima najteže se nose obitelji s nižim primanjima i žene nižega stupnja naobrazbe, pa zbog brige o djeci ili starijim ukućanima dolazi do majčina prekida ili pauze u karijeri. Prekidi zaposlenosti umanjuju ljudski i socijalni kapital žena, ekonomsku nezavisnost i buduću mirovinu (Fultz i Stenhilber, 2004., prema Matković, 2008.).

\section{ISTRAŽIVAČKı CILJEVI}

U analizi prediktora zaposlenosti žena u Hrvatskoj posebna pozornost usmjerena je prema ženama u dobi između 20 i 39 godina. ${ }^{8}$ Promjene koje obilježavaju živote žena u tim dobnim skupinama vrlo su važne za predmetno istraživanje. Neke od značajnijih jesu stjecanje obrazovanja i radnog iskustva, stupanje u brak, rađanje i briga o djeci, izlazak i povratak u zaposlenost i sl. Na tragu navedenog, ponudit će se odgovori na pitanja kako pojedini prediktori, kao dob žene, bračno stanje, broj te starost djece i stupanj obrazovanja, utječu na mogućnosti žena na tržištu rada u Hrvatskoj. Prema dosadašnjim rezultatima, u Hrvatskoj još nisu istraženi prediktori zaposlenosti žena na temelju mikropodataka iz Ankete o radnoj snazi (ARS). Treba naglasiti da postoje i druge važne institucionalne i socioekonomske varijable u predviđanju zaposlenosti žena, kao npr. socijalne politike, zakonska regulativa, dostupnost ustanova za skrb o predškolskoj djeci, dohodak i obrazovanost supruga, ukupan dohodak obitelji i dr., ali one neće biti predmet istraživanja u ovom radu. 
Hipoteze koje će se $u$ radu ispitati jesu:

H1: Razina obrazovanja u pozitivnoj je vezi sa zaposlenosti žena.

H2: Veći broj djece povezan je s nižom stopom aktivnosti žena na tržištu rada.

H3: Dob žene u fertilnoj dobi pozitivno je korelirana s participacijom na tržištu rada.

H4: Veću vjerojatnost sudjelovanja na tržištu rada imaju udane žene.

H5: Imanje djece (djeteta) predškolske dobi u negativnoj je vezi s aktivnosti žena na tržištu rada.

\section{METODOLOGIJA ISTRAŽIVANJA,}

\section{IZVORI PODATAKA I ODABIR VARIJABLI}

Za potrebe ovoga rada uzeti su podaci dobiveni iz Ankete o radnoj snazi (ARS) Državnog zavoda za statistiku Republike Hrvatske. Anketa je jedini službeni izvor mikropodataka na nacionalnoj razini kojim smo mogli obraditi tematiku ovoga rada. Za analizu je uzeto drugo i četvrto tromjesečje ${ }^{9} 2007$. godine. Ukupan uzorak činile su 2462 žene između 20 i 39 godina. S obzirom na temu istraživanja, izbačene su osobe koje su se prema anketi izjasnile kao učenice ili studentice (položaj u aktivnosti), točnije njih 378. Zbog malog uzorka izbačeni su i slabo zastupljeni oblici bračnoga statusa (samo 5,5\% uzorka činile su žene bračnoga statusa: udovice, rastavljene, izvanbračni i odvojeni partneri). Konačni uzorak koji smo izdvojili sadržavao je 1964 žene od 20 do 39 godina. Kao glavna statistička metoda upotrijebljena je multinomna logistička regresija, ekstenzija logističke regresije koja nam omogućuje predviđanje više od dva ishoda kriterijske varijable, $\mathrm{u}$ ovisnosti o odabranim prediktorskim varijablama. Ishod regresije $u$ tom slučaju može biti serija usporedbi između dviju kategorija.

Kriterijska kategorijalna varijabla poprima tri vrijednosti (zaposlena / nezaposlena / neaktivna). Za prediktorske varijable izabrane su bitne socio-demografske determinante (dob, bračno stanje, stupanj obrazovanja, broj djece, imanje predškolskoga djeteta).

U logističkoj regresiji predviđamo vjerojatnost ostvarenja $y$ za dane vrijednosti $x$ (eva). Jednadžba logističke regresije ovog istraživanja, iz koje se predviđa vjerojatnost ostvarenja $y$, glasi:

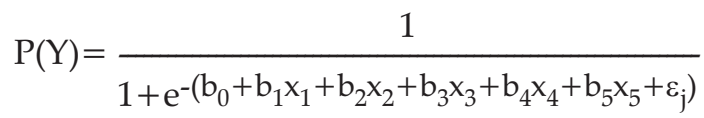

gdje je $\mathrm{P}(\mathrm{Y})$ vjerojatnost ostvarenja y, e je baza prirodnoga logaritma. 


\begin{tabular}{|c|c|c|c|}
\hline \multirow{17}{*}{$\begin{array}{l}\text { TABLICA } 1 \\
\text { Struktura uzorka s } \\
\text { obzirom na analizira- } \\
\text { na sociodemografska } \\
\text { obiliežja }\end{array}$} & \\
\hline & Kategorija & Ukupno & Udio \\
\hline & \multicolumn{3}{|l|}{ Bračno stanje } \\
\hline & Neudane & 718 & 36,6 \\
\hline & Udane & 1246 & 63,4 \\
\hline & \multicolumn{3}{|l|}{ Obrazovanje $\mathrm{e}^{10}$} \\
\hline & Nisko & 281 & 14,3 \\
\hline & Srednje & 1307 & 66,5 \\
\hline & Visoko & 376 & 19,1 \\
\hline & \multicolumn{3}{|l|}{ Imanje predškolskoga djeteta } \\
\hline & Ima & 649 & 33,0 \\
\hline & Nema & 1315 & 67,0 \\
\hline & \multicolumn{3}{|l|}{ Broj djece } \\
\hline & 0 & 819 & 41,7 \\
\hline & 1 & 318 & 16,2 \\
\hline & 2 & 572 & 29,1 \\
\hline & $3+$ & 255 & 13,0 \\
\hline
\end{tabular}

\section{REZULTATI ISTRAŽIVANJA I DISKUSIJA}

\section{Deskriptivna analiza}

Svrha deskriptivne analize jest davanje jasnoga pregleda varijabli i njihova ponašanja $u$ istraživanju. U skladu s očekivanim i već poznatim statistikama (Eurostat, 2010.), koje pokazuju specifične stope zaposlenosti žena prema dobnim skupinama, dobili smo gotovo iste stope i na našem uzorku (Tablica 2). Varijabla "broj djece" uzeta je za ispitivanje povezanosti imanja djece i zaposlenosti. Povećanjem broja djece stope zaposlenosti žena opadaju u svim promatranim dobnim grupama. Također, ako gledamo povezanost imanja djece i druga dva ishoda, nezaposlenost i neaktivnost, onda se prema ukupnim stopama veći broj djece očituje većim porastom stopa neaktivnosti od stopa nezaposlenosti.

Međuodnosi razine obrazovanja žena, broja djece i zaposlenosti prikazani su u Tablici 3. U promatranom uzorku žena prisutna je negativna korelacija stupnja obrazovanja i stope nezaposlenosti žena. Dodamo li kategoriji "obrazovanje" i ukupan broj djece, najviše stope zaposlenosti nalazimo kod žena s visokim obrazovanjem s jednim djetetom ili dva djeteta. U pravilu stope zaposlenosti žena opadaju s povećanjem broja djece, osim kod žena s visokim obrazovanjem, a vjerojatnost da žena bude nezaposlena ili neaktivna raste što je stupanj obrazovanja niži. Navedeno bismo mogli povezati s pravilom da manje obrazovane žene imaju manju vjerojatnost ostanka i kontinuiteta u punoj zaposlenosti od žena s višim stupnjem obrazovanja. Hakim (2004.) nalazi da je utjecaj bro- 
$\rightarrow$ TABLICA 2 Stope zaposlenosti, nezaposlenosti i neaktivnosti žena prema dobnim skupinama i broju djece (\%)

$\rightarrow$ TABLICA Stope zaposlenosti, nezaposlenosti neaktivnosti žena prema stupnju obrazovanja i broju diece $(\%)$ ja djece na zaposlenost veći kod majki s nižim stupnjem obrazovanja. Nadalje, Wenk i Garrett (1992.) smatraju da starije majke s visokim stupnjem obrazovanja i atraktivnijim poslovima imaju manju vjerojatnost napuštanja posla od mlađih i manje obrazovanih.

\begin{tabular}{lrrrr}
\hline Broj djece & Dobna grupa & St. zap. & St. nezap. & St. neakt. \\
\hline Bez djece & & 76,4 & 16,9 & 8,1 \\
& $20-24$ & 74,5 & 16,0 & 11,3 \\
& $25-29$ & 83,3 & 10,6 & 6,8 \\
Jedno dijete & $30-34$ & 72,9 & 20,5 & 8,3 \\
& $35-39$ & 75,4 & 18,9 & 7,1 \\
& & 77,7 & 10,5 & 13,2 \\
& $20-24$ & 84,1 & 7,5 & 9,1 \\
Dvoje djece & $25-29$ & 78,9 & 13,0 & 9,2 \\
& $30-34$ & 78,8 & 5,6 & 16,5 \\
& $35-39$ & 73,5 & 13,5 & 15,0 \\
& & 73,1 & 11,6 & 17,3 \\
Troje i više & $20-24$ & 72,7 & 14,9 & 14,5 \\
& $25-29$ & 73,4 & 7,3 & 20,9 \\
& $30-34$ & 72,4 & 14,2 & 15,7 \\
& $35-39$ & 73,5 & 10,9 & 17,5 \\
& & 59,6 & 16,0 & 29,0 \\
& $20-24$ & 53,1 & 25,7 & 28,6 \\
& $25-29$ & 62,0 & 15,4 & 26,8 \\
& $30-34$ & 64,5 & 9,1 & 29,0 \\
& $35-39$ & 57,5 & 16,0 & 31,5 \\
& & & &
\end{tabular}

\begin{tabular}{lrrrr}
\hline Obrazovanje & Broj djece & Zap. & Nezap. & Neakt. \\
\hline \multirow{2}{*}{ Nisko } & & 48,0 & 20,1 & 39,9 \\
& 0 & 38,5 & 23,1 & 50,0 \\
& 1 & 56,4 & 24,1 & 25,6 \\
& 2 & 51,5 & 19,4 & 36,1 \\
\multirow{3}{*}{ Srednje } & $3+$ & 46,2 & 17,3 & 44,1 \\
& & 75,0 & 14,8 & 12,0 \\
& 0 & 76,9 & 18,4 & 5,8 \\
& 1 & 77,8 & 9,5 & 14,0 \\
Visoko & 2 & 74,6 & 11,8 & 15,4 \\
& $3+$ & 64,6 & 17,0 & 22,2 \\
& & 87,2 & 9,9 & 3,2 \\
& 0 & 83,8 & 12,8 & 3,8 \\
& 1 & 91,4 & 7,0 & 1,7 \\
& 2 & 95,4 & 3,1 & 1,5 \\
& $3+$ & 88,9 & 5,9 & 5,6 \\
\hline
\end{tabular}

Predznak kojim bi se mogla okarakterizirati veza bračnoga stanja i zaposlenosti žena još nije dovoljno istražen. Prema 
DRUŠ. ISTRAŽ. ZAGREB GOD. 20 (2011), BR. 1 (111)

STR. 69-88

GELO, J., SMOLIĆ, Š., STRMOTA, M.: SOCIODEMOGRAFSKE.

$\rightarrow$ TABLICA 4 Stope zaposlenosti, nezaposlenosti i neaktivnosti žena prema dobi i bračnom statusu $(\%)$ dostupnoj literaturi, imanje bračnoga partnera pokazalo se poticajnim, ali i kao kočnica za zaposlenost žena. Hakim (2003.b) ističe ulogu žene kao sekundarnoga hranitelja obitelji, oslanjajući se djelomično ili potpuno na zaradu supruga. $S$ druge strane, bračni partner može biti ženi oslonac u brizi za djecu i na taj način pridonijeti povećanju njezina vremena na tržištu rada. Ono što možemo zamijetiti iz Tablice 4 donekle je negativna veza braka i stope neaktivnosti, odnosno udane žene češće izlaze $s$ tržišta rada nego što to čine njihove neudane vršnjakinje. Unutar udanih može se zamijetiti blaga tendencija porasta neaktivnosti prelaskom u starije dobne skupine. Najugroženije žene koje pak ostaju na tržištu rada jesu one neudane između 30 i 34 godine, kod kojih je - u usporedbi s ostalim dobnim skupinama - stopa nezaposlenosti najviša. Bolje pak prolaze neudane od 25 do 29 godina, kod kojih stopa zaposlenosti iznosi gotovo $82 \%$.

\begin{tabular}{lrrrr}
\hline Bračni status & Dobna grupa & Zap. & Nezap. & Neakt. \\
\hline Neudane & & 75,3 & 17,8 & 8,4 \\
& $20-24$ & 74,4 & 15,9 & 11,6 \\
$25-29$ & 81,6 & 11,9 & 7,4 \\
& $30-34$ & 70,9 & 21,7 & 9,4 \\
Udane & $35-39$ & 75,3 & 19,4 & 6,5 \\
& & 72,4 & 12,0 & 17,7 \\
& $20-24$ & 70,9 & 15,5 & 16,1 \\
& $25-29$ & 74,0 & 10,0 & 17,8 \\
& $30-34$ & 74,0 & 10,2 & 17,6 \\
& $35-39$ & 70,9 & 12,8 & 18,7 \\
\hline
\end{tabular}

\section{Multinomna logistička regresija}

U Tablici 5 prikazane su procjene parametara dobivene multinomnom logističkom regresijom. Procijenjena su dva modela; u prvom modelu promotren je odnos nezaposlenih žena u odnosu na referentnu kategoriju, tj. zaposlene, a $\mathrm{u}$ drugom odnos neaktivnih žena u odnosu na zaposlene. Odabrani podaci uklapaju se u model; proporcija varijacija objašnjenih modelom iznosi oko $12 \%$, značajan doprinos u modelu nema samo kvadrat varijable dob žene.

$\mathrm{U}$ prvom modelu (nezaposlene u odnosu na referentnu kategoriju) većina prediktorskih varijabli, osim dummy varijable imanja predškolskoga djeteta, pokazale su se kao značajan prediktor zaposlenosti. Izgledi da analizirane žene s niskim stupnjem obrazovanja ne budu zaposlene nego nezaposlene dva i pol puta su veći nego kod žena s visokim stupnjem obrazovanja. Da je slabije obrazovanim ženama oportunitetni trošak nezaposlenosti manji, pokazali su Wenk i Garrett (1992.), a Mincer (1985.) veći stupanj obrazovanja žene povezuje s ve- 
DRUŠ. ISTRAŽ. ZAGREB GOD. 20 (2011), BR. 1 (111)

STR. 69-88

GELO, J., SMOLIĆ, Š., STRMOTA, $M$. SOCIODEMOGRAFSKE...

(1) TABLICA 5

Rezultati multinomne logističke regresije

\begin{tabular}{|c|c|c|c|c|}
\hline \multirow[b]{2}{*}{ Aktivnost } & \multicolumn{4}{|c|}{ Referentna kategorija je: zaposlena } \\
\hline & Prediktorska varijabla & $\mathrm{B}$ & $\mathrm{Sg}$ & $\operatorname{Exp}(B)$ \\
\hline nezaposlena & $\begin{array}{l}\text { broj djece } \\
\text { dob žene } \\
(\text { dob žene })^{2} \\
\text { obrazovanje = nisko } \\
\text { obrazovanje = srednje } \\
\text { obrazovanje = visoko } \\
\text { bračno stanje = neudana } \\
\text { bračno stanje = udana } \\
\text { ima predškolsko dijete } \\
\text { nema predškolsko dijete } \\
\text { Intercept }\end{array}$ & $\begin{array}{l}0,223^{*} \\
-0,330^{*} \\
0,004^{* *} \\
0,913^{* *} \\
0,379 \\
0 \\
0,49 * \\
0 \\
0,096 \\
0 \\
3,075\end{array}$ & $\begin{array}{l}0,099 \\
0,146 \\
0,002 \\
0,278 \\
0,204 \\
. \\
0,232 \\
. \\
0,23 \\
\dot{2}, 123\end{array}$ & $\begin{array}{l}1,25 \\
0,719 \\
1,004 \\
2,493 \\
1,461 \\
1 \\
1,633 \\
1 \\
1,101 \\
1\end{array}$ \\
\hline neaktivna & $\begin{array}{l}\text { broj djece } \\
\text { dob žene } \\
(\text { dob žene })^{2} \\
\text { obrazovanje }=\text { nisko } \\
\text { obrazovanje = srednje } \\
\text { obrazovanje = visoko } \\
\text { bračno stanje = neudana } \\
\text { bračno stanje }=\text { udana } \\
\text { ima predškolsko dijete } \\
\text { nema predškolsko dijete } \\
\text { Intercept }\end{array}$ & $\begin{array}{l}0,367^{* *} \\
0,024 \\
0 \\
2,856^{* *} \\
1,374^{* *} \\
0 \\
0,142 \\
0 \\
0,412^{* *} \\
0 \\
-4,384\end{array}$ & $\begin{array}{l}0,08 \\
0,157 \\
0,003 \\
0,331 \\
0,311 \\
\dot{0}, 236 \\
\dot{0}, 185 \\
\dot{2}, 392\end{array}$ & $\begin{array}{l}1,443 \\
1,024 \\
1 \\
17,388 \\
3,951 \\
1 \\
1,153 \\
1 \\
1,51 \\
1\end{array}$ \\
\hline
\end{tabular}

Razine značajnosti: ${ }^{*} \mathrm{p}<0,05 ;{ }^{*} \mathrm{p}<0,01$; referentne kategorije su u kurzivu.

U drugom modelu (neaktivne u odnosu na referentnu kategoriju) značajne su varijable broj djece, obrazovanje i dummy varijabla predškolsko dijete, dok varijable dob žene i bračno stanje nisu značajne. Dodatno dijete povećava vjerojatnost da žena ne bude zaposlena nego neaktivna za oko 45\%. Razloge ovomu možemo naći u slaboj ponudi poslova s nepunim radnim vremenom, nedostatku formalne skrbi za djecu, efektu 
DRUŠ. ISTRAŽ. ZAGREB GOD. 20 (2011) BR. 1 (111)

STR. 69-88

GELO, J., SMOLIĆ, Š., STRMOTA, M.: SOCIODEMOGRAFSKE...

\section{ZAKLJUČAK}

\section{BILJEŠKE}

s nalazima Heckmana i Macurdyja (1980.), pokazalo se da žene s predškolskim djetetom imaju veću šansu (1,5 puta) da budu neaktivne naspram žena koje nemaju dijete predškolske dobi. Najveći utjecaj na status na tržištu rada ima obrazovanje, pa tako žene s niskim obrazovanjem u odnosu na one s visokim stupnjem obrazovanja imaju za oko osamnaest puta veću vjerojatnost da ne budu zaposlene nego neaktivne. Ženama sa srednjim stupnjem obrazovanja izgledi da budu neaktivne četiri su puta veći u odnosu na žene s visokim obrazovanjem.

Odluka o participiranju u plaćenom radu ovisi o mnogim individualnim, društvenim i kulturnim čimbenicima. U ovom radu opisali smo samo jednu skupinu sociodemografskih varijabli koje određuju položaj žene na tržištu rada, a samim tim i njezin položaj u društvu. Obrađene varijable uglavnom su se pokazale kao značajni prediktori zaposlenosti žena. Izabranim uzorkom žena potvrdili smo većinu hipoteza s kojima smo započeli ovo istraživanje. Obrazovanje, broj djece i dob žene pokazale su se kao tri najvažnija prediktora zaposlenosti žena u Hrvatskoj. Najjača veza između ishoda i obrazovanja pokazala se u oba promatrana modela, odnosno žene s niskim obrazovanjem imaju višestruko veću vjerojatnost da ne budu zaposlene nego nezaposlene ili, još češće, neaktivne. Isto tako analiza je pokazala da porastom dobi žene imaju manje šanse da budu nezaposlene. Roditeljstvo je pokazalo negativnu vezu sa zaposlenosti tj. imanje dodatnoga djeteta povećava šanse da žene ne budu zaposlene nego nezaposlene, odnosno neaktivne. Bračni status pokazao se kao značajan prediktor u prvom modelu, pa se može zaključiti da su neudane žene češće nezaposlene. Nadalje, imanje predškolskoga djeteta povezano je s participacijom na tržištu rada, i to tako da takvo dijete povećava šansu da žena ne bude zaposlena nego neaktivna (1,5 puta). Provedeno istraživanje potvrđuje tezu da usprkos postojanju, među zemljama nejednako zastupljenih, politika usmjerenih prema usklađivanju obiteljskoga i profesionalnoga života, velik dio tzv. kućanskih poslova i dalje obavlja žena, a uspjeh na poslovnom planu uvelike će ovisiti o ženinoj motivaciji i snazi u balansiranju između privatnoga i poslovnoga svijeta.

${ }^{1}$ Radi kasnije analize, potrebno je naglasiti da kućanice prema ARS-u mogu biti i aktivne (zaposlene ili nezaposlene) ako su u referentnom tjednu radile 1 sat i za to bile plaćene. $U$ uzorku ovoga rada bilo je 153 kućanice, od toga je njih 138 bilo neaktivno, a samo 9 nezaposleno i 6 zaposleno. 
DRUŠ. ISTRAŽ. ZAGREB GOD. 20 (2011), BR. 1 (111)

STR. 69-88

GELO, J., SMOLIĆ, Š., STRMOTA, $M$ SOCIODEMOGRAFSKE.
2 Stavovi u tim zemljama mogli bi biti zanimljivi, jer se radi o skupini (post)tranzicijskih zemalja sličnih Hrvatskoj.

${ }^{3}$ Becker (1965.) dijeli ponudu rada žene na tržišnu (s ciljem kupovine tržišnih dobara i usluga) i u kućanstou (proizvodnja dobara i usluga u kućanstvu).

4 Becker u ovom radu tumači razliku između "altruističnih" i "sebičnih" roditelja.

5 Jedina je iznimka Italija.

6 Iznimke su Italija, Španjolska i Grčka.

7 Prema Popisu iz 2001., stopa aktivnosti visokoobrazovanih u svakoj petogodišnjoj dobnoj kohorti viša je za oko 20 postotnih bodova od one osoba srednjeg obrazovanja.

8 Žene od 20 do 39 godina analizirali smo u sklopu drugog istraživanja fertiliteta i zaposlenosti žena u toj dobnoj skupini. Nadalje, prema podacima DZS-a, $93 \%$ djece u 2007. godini rodile su majke u toj dobi.

${ }^{9}$ Zbog specifičnoga provođenja ARS-a (4 ponavljajuća panel uzorka u 8 kvartala). Na taj način dobili smo uzorak žena iz različitih kućanstava.

10 Nisko obrazovanje: bez škole, 1-3; 4-7 i 8 razreda osnovne škole. Srednje obrazovanje: škole za obrtnička i industrijska zanimanja i za KV i VKV radnike, tehničke, ekonomske, medicinske i sl. srednje škole, gimnazija. Visoko obrazovanje: viša škola, prvi stupanj fakulteta i stručni studij, fakultet, umjetnička akademija i sveučilišni studij, magisterij, doktorat.

\section{LITERATURA}

Becker, G. S. (1962.), Investment in Human Capital: A Theoretical Analysis. The Journal of Political Economy, Part 2: Investment in Human Beings, 70 (5): 9-49.

Becker, G. S. (1965.), A Theory of the Allocation of Time. The Economic Journal, 75 (299): 493-517.

Becker, G. S. (1981.), Altruism in the Family and Selfishness in the Market Place. Economica, 48 (189): 1-15.

Becker, G. S. i Lewis, H. G. (1973.), On the Interaction between the Quantity and Quality of Children. The Journal of Political Economy, 81 (2): 279-288

Berk, R. A. i Berk, S. F. (1983.), Supply-Side Sociology of the Family: The Challenge of the New Home Economics. Annual Review of Sociology, 9: 375-395.

Bianchi, S. M. (2000.), Maternal Employment and Time with Children: Dramatic Change or Surprising Continuity? Demography, 37 (4): 401-414.

Billari, F. C. i Kohler, H.-P. (2002.), Patterns of Low and Lowest-Low Fertility in Europe. Population Studies, 58 (2): 161-176.

Brewster, K. L. i Rindfuss, R. R. (2000.), Fertility and Women's Employment in Industrialized Nations. Annual Review of Sociology, 26: 271-296. 
DRUŠ. ISTRAŽ. ZAGREB GOD. 20 (2011), BR. 1 (1111)

STR. 69-88

GELO, J., SMOLIĆ, Š., STRMOTA, $M$.: SOCIODEMOGRAFSKE.
Del Boca, D., Pasqua, S., Pronzato, C. (2004.), Why are Fertility and Women's Employment Rate so Low in Italy? Lessons from France and the U. K., IZA Discussion Papers, No. 1274.

Del Boca, D. i Pasqua, S. (2005.), Labor Supply and Fertility in Europe and US. U: T. Boeri, D. Del Boca i C. Pissarides (ur.), Women at Work: An Economic Perspective (str. 125-153), New York: Oxford University Press.

Ekert-Jaffe, O. i Stier, H. (2009.), Normative or Economic Behaviour? Fertility and Women's Employment in Israel. Social Science Research, 38: 644-655.

Engelhardt, H., Kögel, T. i Prskawetz, A. (2004.), Fertility and Women's Employment Reconsidered: A Macro-Level Time-Series Analysis for Developed Countries 1960-2000. Population Studies, 58 (1): 109-120.

Eurostat (2010.), Employment and Social Policy Indicators. Dostupno na: http://epp.eurostat.ec.europa.eu/portal/page/portal/employment and social_policy indicators/introduction (5. 7. 2010.).

Galić, B. i Nikodem, K. (2009.), Neki aspekti diskriminacije žena pri zapošljavanju u Republici Hrvatskoj. U: V. Franičević i V. Puljz (ur.), Rad u Hrvatskoj: pred izazovima budućnosti (str. 107-130), Zagreb: Centar za demokraciju i pravo Miko Tripalo.

Grossbard-Shechtman, S. A. (2003.), Marriage and the Economy, Cambridge: Cambridge University Press.

Hakim, C. (2003.a), A New Approach to Explaining Fertility Patterns: Preference Theory. Population and Development Review, 29 (3): 349-374.

Hakim, C. (2003.b), Models of the Family in Modern Societies: Ideas and Realities, Ashgate Publishing Company, USA.

Hakim, C. (2004.), Key Issues in Women's Work: Female Diversity and the Polarisation of Women's Employment, 2nd ed., London: Routledge-Cavendish.

Heckman, J. J. i Macurdy, T. E. (1980.), A Life Cycle Model of Female Labour Supply. The Review of Economic Studies, 47 (1): 47-74.

Jaumotte, F. (2003.), Female Labour Force Participation: Past Trends and Main Determinants in OECD Countries, OECD Economics Department Working Papers, No. 376.

Kerovec, N. (2003.), (Ne)jednakost žena na tržištu rada. Revija za socijalnu politiku, 10 (3): 263-282.

Leinert Novosel, S. (2003.), Politika zapošljavanja žena. Politička misao, 40 (3): 103-127.

Leutar, Z. (2004.), Žena između svijeta rada i obitelji. Društvena istraživanja, 13 (6): 1159-1177.

Matković, T. (2008.), Tko što radi? Dob i rod kao odrednice položaja na tržištu rada. Revija za socijalnu politiku, 15 (3): 479-502.

McConnell, C. R., Brue, S. L. i MacPherson, D. A. (2007.), Contemporary Labor Economics, New York: McGraw-Hill.

Mendras, H. (2004.), Europa i Europljani: sociologija Zapadne Europe, Zagreb: Masmedia. 
DRUŠ. ISTRAŽ. ZAGREB GOD. 20 (2011), BR. 1 (111) STR. 69-88

GELO, J., SMOLIĆ, Š., STRMOTA, $M$. SOCIODEMOGRAFSKE...
Mincer, J. (1985.), Intercountry Comparisons of Labor Force Trends and of Related Developments: An Overview. Journal of Labor Economics, 3 (1): 1-32.

Pissarides, C., Garibaldi, P., Olivetti, C., Petrongolo, B. i Wasmer, E. (2005.), Women in the Labor Force: How Well is Europe Doing? U: T. Boeri, D. Del Boca i C. Pissarides (ur.), Women at Work: An Economic Perspective (str. 7-120), New York: Oxford University Press.

Rindfuss, R. R. i Brewster, K. L. (1996.), Childrearing and Fertility, Population and Development Review, 22, Supplement: Fertility in the United States: New Patterns, New Theories: 258-289.

Stier, H., Lewin-Epstein, N. i Braun, M. (2001.), Welfare Regimes, Family-Supportive Policies, and Women's Employment along the Life-Course Source. The American Journal of Sociology, 106 (6): 1731-1760.

Topolčić, D. (2001.), Muškarci to ne rade: rodno segregirana podjela rada u obitelji. Društvena istraživanja, 10 (4-5): 767-789.

Topolčić, D. (2008.), Udio žena u tržištu rada, obrasci radne karijere i uloga države. Društvena istraživanja, 98 (6): 1023-1046.

Treas, J. i Widmer, E. D. (2000.), Married Women's Employment over the Life Course: Attitudes in Cross-National Perspective. Social Forces, 78 (4): 1409-1436.

Waldfogel, J. (1997.), The Effect of Children on Women's Wages. American Sociological Review, 62 (2): 209-217.

Wenk, D. i Garrett, P. (1992.), Having a Baby: Some Predictions of Maternal Employment Around Childbirth. Gender and Society, 6 (1): 49-65.

\section{Socio-Demographic Determinants of Female Employment in Croatia}

Jakov GELO, Šime SMOLIĆ, Marin STRMOTA

Faculty of Economics and Business, Zagreb

In this paper the authors define the effects of selected socio-demographic predictors - age, education, number of children, marital status of women and having a preschool child - on female employment in Croatia. In the very first part of this article a vast review of literature relating to the research of the causes and consequences of female labour force participation is presented. The findings in this paper are based on the analysis of the micro data from the Labour Force Survey in the second and fourth quarters of 2007. A total number of 2462 women were included in the sample; though some groups of women were excluded afterwards, e.g. women still schooling and some less represented marital status profiles (divorced, widowed etc.). In the second part of the paper the authors use descriptive data analysis relating the independent variables to the three variations of a dependent variable. Moreover, in order to identify the 
DRUŠ. ISTRAŽ. ZAGREB GOD. 20 (2011)

BR. $1(111)$

STR. 69-88

GELO, J., SMOLIĆ, Š., STRMOTA, M.: SOCIODEMOGRAFSKE. significant predictors of female employment, a multinomial logistic regression (logistic regression extension) is employed. Education, number of children, age of woman, marital status and having a preschool child are the significant predictors of female employment while marriage status is not significant in the model.

Keywords: female labour force participation, education of women, number of children, employment

\section{Soziodemografische Merkmale berufstätiger Fraven in Kroatien}

Jakov GELO, Šime SMOLIĆ, Marin STRMOTA

Wirtschaftswissenschaftliche Fakultät, Zagreb

Die Autoren dieser Arbeit wollen ermitteln, welche Auswirkungen die soziodemografischen Prädiktoren Alter, Bildungsstand, Kinderzahl, Ehestand und Vorhandensein eines Kindes im Vorschulalter auf die Berufstätigkeit von Fraven in Kroatien haben. Der erste Teil der Arbeit bringt einen umfangreichen Überblick über die bestehende Fachliteratur, die sich mit Ursachen und Folgen der Beteiligung von Fraven am Arbeitsmarkt beschäftigt. Eine empirische Analyse beruft sich auf Daten, die in einer entsprechenden Umfrage zur Ermittlung der Arbeitskräfteverteilung (ARS) im 2. und 4. Quartal des Jahres 2007 gewonnen worden waren. An der Umfrage beteiligten sich 2462 Fraven im Alter von 20 bis 39 Jahren; nicht berücksichtigt wurden dabei Schülerinnen und Studentinnen sowie Witwen, geschiedene Fraven und ähnliche seltener vertretene Formen des Ehestands. Der zweite Teil der Arbeit enthält eine deskriptive Analyse und setzt die genannten Prädiktorvariablen in Bezug zu drei Modalitäten von Kriteriumsvariablen. Mittels multinomischer logistischer Regression gaben die Verfasser eine Einschätzung zweier Modelle: der Gruppe nicht berufstätiger Fraven im Verhältnis zur Referenzkategorie der berufstätigen Fraven, und stellten dabei bedeutende Prädiktoren bei den Berufstätigen fest. Bildungsstand, Kinderzahl, Alter, Ehestand und das Vorhandensein eines Kindes im Vorschulalter können als bedeutende Prädiktoren für die Berufstätigkeit von Fraven in Kroatien betrachtet werden.

Schlüsselbegriffe: Beteiligung von Fraven am Arbeitsmarkt, Bildungsstand von Fraven, Kinderzahl, Berufstätigkeit 